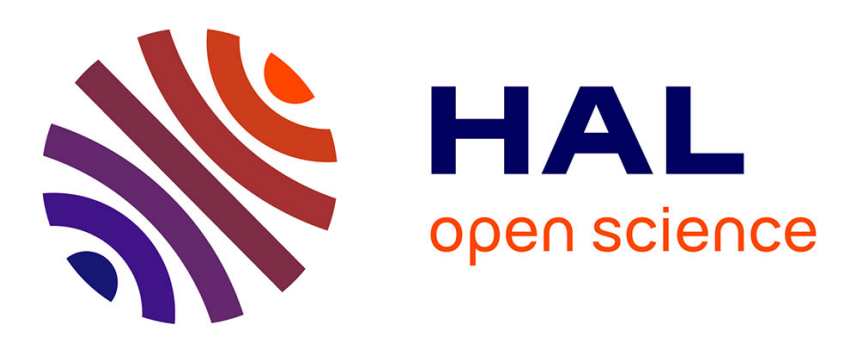

\title{
From multi-utility to cross-utilities: the challenges of cross-sectoral entrepreneurial strategies in a German city
}

\author{
Daniel Florentin
}

\section{To cite this version:}

Daniel Florentin. From multi-utility to cross-utilities: the challenges of cross-sectoral entrepreneurial strategies in a German city. Urban Studies, 2019, 56 (11), pp.2242-2260. 10.1177/0042098018798974 . hal-02189533

\section{HAL Id: hal-02189533 \\ https://hal.science/hal-02189533}

Submitted on 22 Jul 2019

HAL is a multi-disciplinary open access archive for the deposit and dissemination of scientific research documents, whether they are published or not. The documents may come from teaching and research institutions in France or abroad, or from public or private research centers.
L'archive ouverte pluridisciplinaire HAL, est destinée au dépôt et à la diffusion de documents scientifiques de niveau recherche, publiés ou non, émanant des établissements d'enseignement et de recherche français ou étrangers, des laboratoires publics ou privés. 


\title{
From multi-utility to cross-utilities: the challenges of cross-sectoral entrepreneurial strategies in a German city.
}

\author{
Daniel FLORENTIN, Assistant Professor, Mines Paris Tech, ISIGE, PSL University
}

\begin{abstract}
In the water and energy sectors, projects geared towards new forms of cross-sectoral functioning have boomed in most European countries over the past decade, and have deeply transformed the ecology of urban services. These projects are often considered as an answer to a rising challenge affecting numerous traditional utilities: the unforeseen urban change relating to shifting (i.e. declining) demand patterns that are undermining traditional models of infrastructure management. The development of cross-sectoral strategies is considered a way both to tackle the attrition of traditional sources of revenue and to develop greener infrastructure systems by enhancing their efficiency level, often in line with low-carbon programmes implemented by national or local governments. Its appeal lies in a fairly static perception of infrastructure management and technological change. Based on a detailed analysis of a traditional German local multi-utility and informed by a 6-month internship within the company, the article deciphers the rationale of multi-sectoral practices, in particular the company's transformation into a cross-utility that devised a common strategy for all SWM's infrastructure networks and its ambiguities. Various facets of such "boundary work" are analysed, focusing on organisational and financial aspects to reveal the new sites of tensions and negotiations between sectors, but also on the material component of these cross-sectoral projects through the case of one such nexus programme, a waste-to-energy programme. This programme embodies the potential contradictions between the call for reduced use of resources (i. e. the production of less waste) and the development of new urban technical systems relying primarily on those same resources.
\end{abstract}

Keywords: urban infrastructures - district heating - waste management - cross-sectoral dynamics - modernisation of utilities - Germany

Does a more sustainable development of cities and their technical networked infrastructures require cross-sectoral projects? The growing body of literature on the necessity to develop more integrated inter-sectoral projects (Pittock, 2011; UNESCO, 2014) and to further develop a water-energy(-food) nexus (Beddington, 2009; Williams et al., 2014) could be considered as an indirect plea for such a form of networked infrastructure, which would transform the urban metabolism. This article critically discusses these ideas of integration and cross-sectoral dynamics, in line with the idea that they should not represent a panacea per se. It argues that they enable new opportunities, yet are mainly resource-efficiency oriented and often barely take into account the multi-scale impacts they may have and hence underestimate the politics of scales they are transforming. 
Most of the literature on nexus issues is enshrined in a context of resource scarcity (Scott et al., 2011), which is then considered as a trigger for the development of cross-sectoral projects (Leck et al., 2015). Such a literature also focuses mainly on cross-sectoral projects but rarely on a larger scope, i.e. cross-sectoral entrepreneurial strategies. These will also be considered here through a method detailing the utility perspective and everyday practices within the company, which are pivotal to the understanding of urban changes as the utility and the urban both coevolve. This article intends to shed light on a different configuration, where cross-sectoral dynamics are driven by a different form of crisis, i.e. the transformation, in many cities of the global North, of demand patterns that are no longer growing. This should both enlarge the perspective on cross-sectoral issues and show their potential ambiguities.

This paper therefore starts where two recent concerns, strategic to both utilities and urban decision-makers, have largely overlapped. The first relates to recent developments in industrial synergies or symbioses and the transformation of energy systems. These developments have materialised in several European countries through the enactment and implementation of proactive legislations advocating what is called an energy transition towards a low carbon energy use (Jaglin and Verdeil, 2013). One of their principles consists in lowering the pressure on limited natural resources and limiting greenhouse gases emissions by pooling resources for various uses. This translates into the development of new uses, cross-sectoral projects and diminished consumption levels for water or energy systems. The second concern has to do with a radical transformation of the functioning of utilities, with the reversal of traditional growthoriented trajectories (Author, 2015; Coutard, 2010), largely due to changing demand patterns. Over the last couple of decades, in most of European cities, water consumption levels and more recently energy consumption levels have decreased (Author, 2015; Barraqué et al., 2011). This has deeply affected the traditional business model of urban utility companies that rests on a continuous growing demand. As they both result in diminished consumption levels, these two processes overlap and their combination creates the conditions and more pressure to change for a new "infrastructure regime" (Monstadt, 2009). Changing demand patterns force the utilities to reinvent their practices and business models. As such, cross-sectoral perspectives offer the possibility to mutualise some infrastructure costs and to produce energy differently: they have been seen as an opportunity for utilities to restructure and re-stabilise their destabilised traditional modus operandi. This article will consider this idea of cross-sectoral dynamics from this perspective.

The combination of the development of cross-sectoral dynamics and new demand patterns produces "new infrastructural ecologies" (Coutard and Rutherford, 2016), that is an infrastructure re-bundling and transformation of technological systems and new configurations of infrastructure actors. This article unpacks both the benefits and the contested nature of this re-bundling. By re-politicising issues of cross-sectoral dynamics, it analyses whether this form of infrastructure-bundling would only displace former sources of vulnerabilities, or produce new vulnerabilities affecting all infrastructure networks and describe how this reshapes the relation between utilities and the territory in which they are located.

These cross-sectoral dynamics will be examined in the following sections through specific lenses: an oriented review of the existing literature on the subject, and an analysis of the transformation of a German municipal multi-utility (where I spent six months as an embedded researcher and an intern) into a "cross-utility". Taking into account this utility perspective helps 
me to identify cross-sectoral practices and how they are shaped by and shape the urban, thus leading to both technical and governance transformations.

In the following sections the methodological protocol and its contribution to the understanding of cross-sectoral dynamics is presented. I then discuss the relatively un-politicised nature of research on these dynamics and their lack of integration of scalar aspects. This is exemplified through the case study of the transformation of Magdeburg's multi-utility (Städtische Werke Magdeburg, SWM), focusing on both its general mutation into a cross-utility, and the development of a specific cross-sectoral project of waste-to-energy. This will lead to a discussion of the new vulnerabilities and governance issues that are raised by one such new configuration.

\section{Methodological aspects: embedded in a utility}

To flesh out the reorganisation of a municipal utility and better capture the "socio-technical geometry of powers in town" (Graham and Marvin, 2001), I decided to immerse myself directly in this technical world by being embedded within the teams of infrastructure management of a German multi-utility. This local utility based in the regional capital of the Land of SaxonyAnhalt, in the Eastern part of Germany, has mixed capital (54\% of the shares are held by the city, $27 \%$ by the power company E.ON Avacon and $19 \%$ by the water and energy company Gelsenwasser). It supplies the city with water, wastewater, central district heating, gas and electricity.

Although the transformation of one utility does not reflect the evolution of all utilities, this one was selected for being representative for similar processes of utility restructuring across Germany and Europe (Schöneich, 2012). The case study thus gives an in-depth perspective on ongoing reorganisations and power redistributions with other urban stakeholders, seen from the utility perspective. These local multi-utilities, which are quite common in many European countries such as Switzerland, Germany or Austria, have long been characterised by the juxtaposition of its various branches - if not an uncoordinated squabble between its various branches (Schulz-Nieswandt, 2012). The multi-utility status was contradicted by the almost total absence of a cross-sectoral strategy or cross-sectoral practices. Recent and rapid crises have forced them to transform their nature and functioning and to give more room to dialogue between the various sectors. As one network manager said, "we were used to working only for one sector, ignoring the other parts of the company, though the company is theoretically a multiutility. But we had to change, to adapt to new conditions, such as, for instance, the liberalisation of energy markets. It was no longer possible to remain with this functioning, i.e. a juxtaposition of small chapels" (discussion with a SWM network manager, April 2013). Analysing such a type of actor thereby informs us about both innovative cross-sectoral dynamics and the restructuring of traditional actors in the urban networks industry.

Former studies on multi-utilities were predominantly dominated by legal approaches (Gottschalk and Bräunig, 2012) or historical descriptions of the construction of multi-utilities (Krämer, 1993; Ambrosius, 2012). Yet, they did not reflect the evolutions of practices, technical and financial models, and incremental transformation towards a more integrated system. The ethnographic approach conducted here endeavours to fill this gap and to complement studies 
on practices centred on infrastructure users (Gelings, 1996; Shove, 2016; van Vliet et al., 2005) by analysing practices from the supply-side and notably practices of utilities' employees (Guigo, 1994). Attention to everyday practices may risk to smoothen confliction within the utility and needs to be complemented by an analysis of specific projects. Cross-sectoral projects are only one specific facet of these practices, yet an interesting momentum where social and technical dynamics are assumed to cross and possibly to reveal conflicts within the utility and with the other urban stakeholders.

This approach is inspired by the principles of analytic induction (Katz, 2001a) and Katz's idea of analysing an object such as a utility through a description of its actors' crafted, anchored and situated behaviours. It coincides with Callon's plea to "look over the shoulders" of engineers to better understand their practices (Callon, 1987) or Berry's recommendation to develop ethnological protocols in companies by "observing in detail" the practices of men, factories and offices (Guigo, 1994, p.7).

This should give a more dynamic perspective on infrastructures-in-the making (Edgerton, 1999) and emphasise the social dynamics at stake in the forming of new infrastructural arrangements. It thus provides a better understanding on where and how actors are (re-)bundling heterogeneous systems.

The very idea of such a methodology consists in showing the functioning of a living and changing system moved by both social urban actors and material infrastructures, focusing rather on the "how" than on the "why" human and non-human actors are acting in one way or another (Katz, 2001b). Such immersion within the utility produces results that semi-structured interviews with experts and professionals or simple data analysis (which were carried out in parallel) cannot provide: daily presence that has radically transformed the discourse of my interlocutors, my perception of the ongoing challenges faced by the utility and my understanding of its strategy.

In this perspective, cross-sectoral dynamics are not only a discourse and are not limited to one infrastructure project promoting synergies, if not symbioses, they are also anchored in behaviours and in everyday practices that contribute to a manifold transformation of the urban environment. They appear to be at the core of the complex reorganisation and modernisation of the local utilities in the tumultuous context of energy transitions and changing demand regime experienced by them, even though, as a review of the existing literature reveals, such transformation remains largely economically-oriented, partly de-politicised and insufficiently spatialised.

\section{Literature review: placing cross-sectoral dynamics in urban politicised contexts}

The burgeoning literature on hybridised infrastructures and the development of cross-sectoral projects has popped up in the public debate as part of larger discussions about a possible urban sustainability through the transformation of water and energy systems. Three main aspects will be discussed in this section. 
The development of cross-sectoral projects or more integrated infrastructure management are often analysed through one specific lens, a context of resource scarcity (Beddington, 2009; Scott and Pasqualetti, 2010). Several studies primarily examine how to be more resourceefficient (Santhosh et al., 2014) to ensure cities' water and energy supply. This becomes quite noticeable in the geography of the cases on forms of hybridisation of heterogeneous infrastructures analysed, where there is an over-representation of cases where water (or, more related to emissions control, energy resources) resources are of a particularly scarce, such as in Spain (Hardy et al., 2012) or California (Cousins and Newell, 2014; Scott et al., 2011).

However, this push for more integrated management of water and energy is not limited to these types of situations of scarcity of natural resources. The driver should rather be conceptualised in terms of crisis, of which resource scarcity is only one facet. Other forms of crises have consequently been partly overlooked, although they may also trigger cross-sectoral dynamics. This is in particular the case of changing demand patterns, which constitutes one of the manifestations of a larger crisis of Large Technical Systems (LTS) (Coutard, 2010; Coutard and Rutherford, 2016). LTS have been characterised by high fixed costs (Summerton, 1994), mainly financed by a steadily but continuously growing consumption. Studies in European urban contexts show the perturbation of such equilibrium, due to changing demand patterns and the lowering of consumption levels (Author, 2015; Barraqué et al., 2011; Hillenbrand et al., 2008; Moss, 2008). From a utility perspective, income is decreasing, while high fixed costs are stable if not increasing (Kluge and Scheele, 2008), due to growing needs for general or sanitary security issues. The transformation of demand patterns alters not only the technical functioning of the infrastructures, as documented by Moss (2008) or Naumann and Bernt (2009), but also their economic stability and consequently some of the urban equilibriums, for these technical networks are essential components of the urban metabolism. One way to address such a crucial challenge for both utilities and their urban environment might either be to resize a network in small decentralised mini-networks. This may indirectly augment the individual burden of infrastructure costs, or to mutualise some of these costs through the pooling of heterogeneous systems. Hybridisation of infrastructures or the development of cross-sectoral infrastructures has thus become a way to adapt to this financial and technical challenge, by mutualising high fixed infrastructure costs. This is exemplified by the development of projects ranging from wastewater to energy (Means, 2004; Moss and Hüesker, this issue) or the use of waste heat from various industrial processes.

Cross-sectoral projects consequently need to be critically examined not only in terms of resource-scarcity, but also in terms of the mismatch between supply and demand. In this respect it may be seen as as a potential answer to a manifold urban infrastructure crisis, not only focused on the supply-side (resources) but also on the demand-side (consumption). This is all the more important as these changing demand patterns are now political objectives behind many laws, and are turning them into a new demand regime. Such an approach is in line with the idea developed by Rutherford (2014) of a rematerialisation of urban studies: adapting infrastructures to these new demand patterns can be interpreted as one facet of the contemporary forms of urban change. Cross-sectoral projects consequently need to be deciphered through both their materiality and the socio-political discourse that surround this materiality, to analyse "how things come to matter to the various interest groups of [...] cities in the making" (Rutherford, 2014, p. 1452). 


\section{Cross-sectoral projects and the politics of scale}

Deciphering re-bundling practices may also help to re-politicise the literature on cross-sectoral dynamics. As detailed by Williams et al. (2014) in a thorough survey, many of the academic analyses on cross-sectoral projects or the water-energy-food nexus largely overlook its political and spatial dimensions. More integrated management and growing hybridisation of infrastructures are often considered, in a quasi-self-fulfilling prophecy, as unequivocally good for the environment ${ }^{1}$, when they are not simply mimicking a fairly market-based approach.

Many studies emphasise the ecological benefits of nexus approaches or of the mutualisation of infrastructures (Cousins and Newell, 2014). However, they tend to underestimate the governance challenges that such a transformation is producing. The implementation of crosssectoral dynamics requires new forms of coordination, which are highly political ${ }^{2}$ (Goldthau, 2014) and may result in new power relationships between the various actors involved in crosssectoral dynamics (between sectors or with the utility's shareholders). This is of paramount importance for multi-utilities like the German Stadtwerke, where the local government, when it is a shareholder, historically exerts a massive influence on the utility, mainly to capture a share of the profits (Monstadt, 2007) and internalise them in the local budget. Along with Williams et al. (2014), in this article I want to go beyond the technology-focused interpretations of these nexus issues and favour a socio-technical and scalar approach.

This scalar approach is particularly decisive to evaluate the effects of cross-sectoral dynamics. As mentioned by Goldthau (2014), cross-sectoral projects are often thought of at a very local level, even though they claim to address issues at a larger scale (ibid. 2014). Scale is here understood not only as a metrics, but as a relational process (Howitt, 1998), reflecting social relations and power issues (Swyngedouw, 1997). Following Marston (2000), attention is hence paid to both the discursive nature of scale and its materiality, or, to be more precise, its material consequences. Cross-sectoral dynamics are consequently contributing to a transformation of the infrastructure and urban landscape and also to new scalar configurations, i.e. a redistribution of power with local actors that need to be unpacked.

\section{Cross-sectoral dynamics and vulnerabilities}

The idea that more integration between sectors would lead to an undisputable bettering of social and environmental conditions precludes the possibility of examining cross-sectoral dynamics not only as inherently contested but also as a factor of vulnerability. However, the bundling of infrastructure systems reinforce the potential risks associated with mono-sectoral infrastructure management (Williams et al., 2014). As Little (2002) has shown and following Perrow's principle of Normal Accidents, the coupling of infrastructures can contribute to new (technical and economic) vulnerabilities of these systems. According to them, complex coupled systems can "predictably fail, but in unpredictable ways", and may have cascading effects. The

\footnotetext{
${ }^{1}$ see for instance Possmopoulous et al., 2009 on a depoliticised analysis of waste to energy; or Kothari et al., 2010 on technical optimisation of infrastructure systems; or Bazilian et al., 2013 on the link between more integration and the enhancement of welfare

${ }^{2}$ As Goldthau says: "Balancing the need for large-scale infrastructure with local and contextualised solutions therefore presents an unprecedented governance challenge” (Goldthau, 2014, p.1)
} 
integration of various infrastructure systems requires that we take into consideration the fact that these systems are thus becoming more interdependent and consequently more vulnerable (Monstadt, 2009). A higher efficiency and interconnectedness can result in a higher vulnerability. Since infrastructures are at the core of the urban fabric (McFarlane and Rutherford, 2008), socio-technical vulnerability and failures can translate into urban vulnerabilities and crises.

In the following sections, the rise of cross-sectoral dynamics is analysed through the case study of the German multi-utility SWM from Magdeburg, in light of its link to a crisis situation, its anchorage within practices, its potentially contested nature, and its potential production or displacement of forms of urban and infrastructural vulnerabilities.

\section{Magdeburg and its multi-utility: an example of cross-sectoral dynamics}

The driver of a cross-sectoral perspective: a context of crisis

German municipal multi-utilities have long been working in "silos", all the sectors being technically and strategically juxtaposed rather than coupled, in spite of their social and political representation as an integrated utility (Ambrosius, 2012). The capital of Saxony-Anhalt, Magdeburg, and its multi-utility SWM is no exception in this regard. Yet a series of crises, which have a local component but are also echoed in the German and Central-Eastern European context, has turned out to be a push to the development of cross-sectoral dynamics.

The multi-utility has been affected by a combination of crises of various intensities and scales that have disrupted its traditional functioning. Processes of urban shrinkage, as well as the challenging of Large Technical Systems and the new challenges of energy transition have deeply transformed the utility.

Like almost every Eastern German city, Magdeburg was deeply affected by urban shrinkage, which is quite integral to post-socialist transition (Golubchikov et al., 2014; Sykora and Bouzarovski, 2012). The city lost above one fifth of its population between 1988 and 2015, reaching around 235,000 inhabitants in 2015. Almost all the industrial sites of machine building industry had closed by 1994-1995, leaving around 100,000 people jobless. Even though the population has stabilised over the last decade and grown slightly since 2013, no structuring industry has developed ever since, and the productive sphere of the city remains quite poor. This twofold process of deindustrialisation and depopulation was completed by energy and water efficiency policies based on important investment programs in infrastructure modernisation in the 1990s. This resulted in a steep drop of consumption levels in all the networks managed by the utility: a decline of water consumption levels of $70 \%$ and over $60 \%$ regarding district heating ${ }^{3}$ (graph 1). In the district heating systems, volumes produced and consumed dropped from $800 \mathrm{GWh}$ in 1993 to 300 in 2012. As the heat or water consumed is now almost entirely due to household consumption, the networks are largely oversized.

A consequence of these oversized networks is an increase of maintenance costs in all the sectors and a reduction of the technical and economic efficiency of the networks (Moss, 2008),

\footnotetext{
${ }^{3}$ Similar figures can be found in other Eastern German cities.
} 
producing a form of scissors effect: heat losses are getting higher while consumed volumes are decreasing. Though this has not been conceptualised as such by researchers, this new context is conceived in terms of crisis by the operators and pleads for a change of the (technical and) economic model of water or energy networks. Without any transformation of network management, the local multi-utility model is seriously endangered. This type of crisis deeply affects cities' budgets, which are dependent on economic results of the utility, as local governments, like in Magdeburg, often restrict their interaction with the utility to a financial one (Fender and Poupeau, 2007). ${ }^{4}$

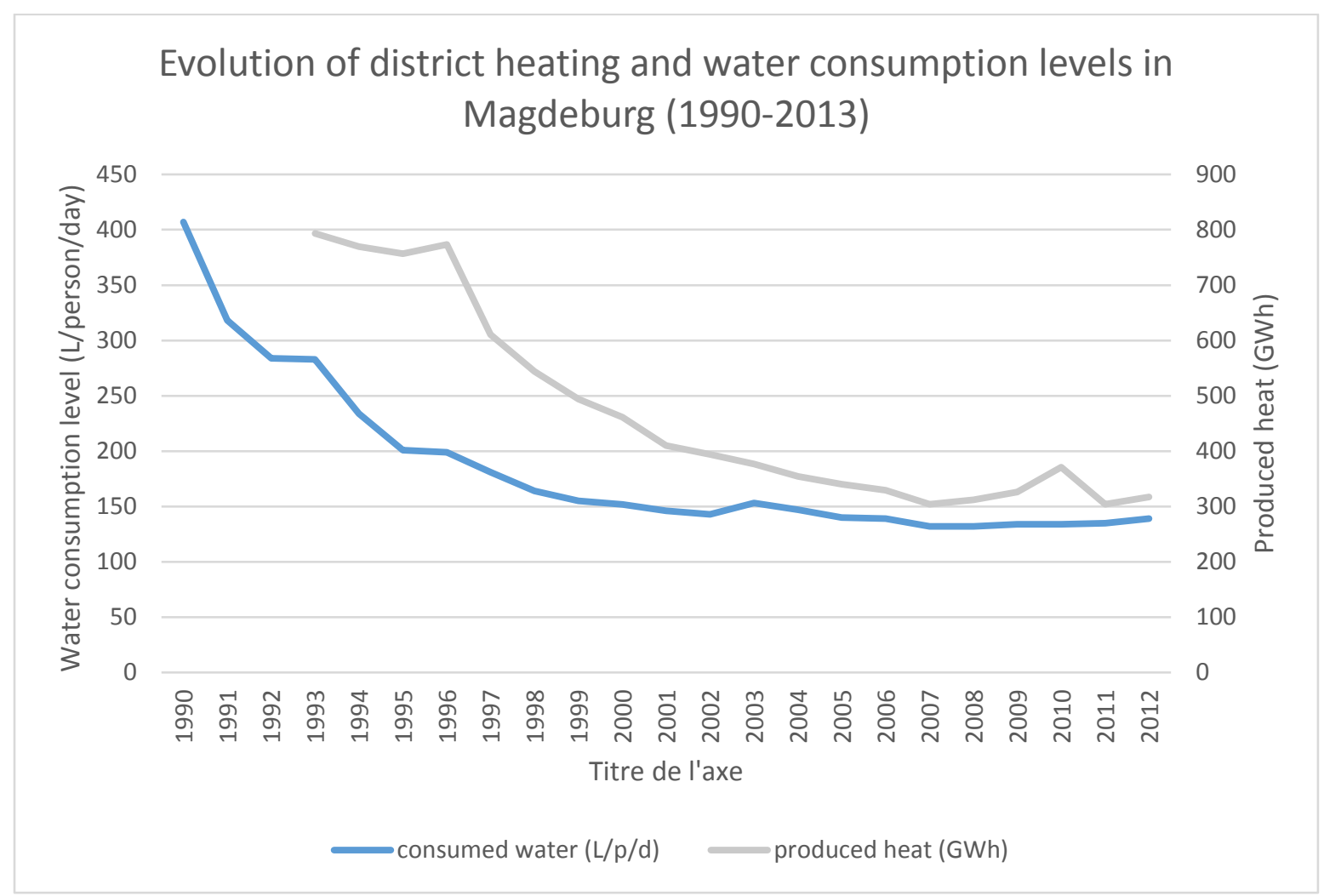

Graph 1 : Evolution of district heating and water consumption levels in Magdeburg (19902012)

Source: data from SWM

The intensity of the crisis has tended to reinforce the Stadtwerk-thinking, that is, the idea of coupling urban networks, or at least delineating new forms of synergies. In Magdeburg, as in other similar cases, the driver of the quest for synergies between sectors was not any form of resource scarcity. On the contrary, resources were abundant enough, and fewer uses of natural resources of water for instance led to urban inconveniences such as the flooding of cellars in

\footnotetext{
4 This type of interaction was corroborated by interviews with representative of various political parties: "The company is working well. I see no reason to intervene, as long as it works and bring money to the city's budget. I see no reason to re-municipalise it" (elected representative of Die Linke, May 2013); " The Stadtwerk is a sound local utility: we let them work quite independently" (elected representative of the Green Party, April 2013).
} 
numerous parts of the city (LHW, 2012), due to the rise of the groundwater table. The driver of a radical transformation of the utility and the exploration of potential coupling or synergies was rather a crisis of inadequacy between demand and supply; in other words, the technical and economic instability of the utility caused by changing demand patterns and the correlative decline of its income. "Beforehand, we (gas, electricity, water, wastewater and waste management) were quite separated. The necessity to balance our budget, to compensate for losses of the public transportation systems or the city government's claim for higher dividends have forced us to think, in each and every service, of how and where we could be more efficient" (discussion with a Stadtwerk network manager, May 2013). Sectoral transformations and political pressure from the local government to extract higher dividends have consequently converged to foster new technical trajectories.

Coupling sectors and developing cross-sectoral synergies has been one of the company's strategies to adapt to this new context. This has followed a twofold pathway: an organisational part driven by the implementation of new cross-sectoral practices, a material part through the development of a new district heating system coupled with waste management and energy supply.

\section{Emerging cross-sectoral practices: from multi-utility to cross-utility}

The cross-sectoral turn within the multi-utility dates back to the mid-2000s, when declining consumption levels were considered a long-term issue and not a short period of crisis that would be soon overcome and compensated for. It was initiated by the utility's Board and largely pushed by its financial management, which was probably echoing financial demands made by the city authorities to extract larger dividends.

A vast restructuring of the utility took place, aimed at enhancing synergies between the different industrial sectors of the company. Integrated management was envisaged at a threefold level: commercial, technical and financial, creating an alignment of practices. "We have tried over the last years [since 2008-2009] not to have troops separated in the different sectors (Sparten) anymore, but to have a transversal structure (spartenübergreifend) to make sectors work together. On the commercial side of the company, we have actually done this for a while. We have decided to implement it also in the technical management of the company, to link functions and find adequate synergies" (conversation with a manager of the finance department, January 2014).

In the field, employees of the multi-utility now have to be competent in different sectors and can intervene in water, heating, gas or electricity issues. "Our service technicians (Monteure), they are not specialised in only one sector; when they go and visit the customers, they take care of all the networks, on the same box. For us, this constitutes a major gain, and for the clients, this is also better, as everything is carried out by only one company and all at once" (conversation with a network manager, March 2013). In the operational field, this transformation has led to the fostering of new cross-sectoral skills for the employees.

The reorganisation of the technical departments has in fact reached all levels of operations up to the general management. Within this quest for a cross-sectoral thinking, the networks management team has also been transformed: one team of engineers now directly establishes a 
common strategy for water, gas and heating systems (and often electricity), where every engineer keeps a sector of expertise. This department for network operations (Netzbetrieb) has a strategic and managerial component, and gives directives to the operative distribution department (Vertrieb). An integrated structure has thereby replaced the juxtaposition of sectoral management and is supposed to take into account constraints and needs of all the sectors before taking a decision regarding one or two sectors. This often implies a more integrated coordination with technicians from the city government, which is still working in "silos" (with the traditional separation of departments): the higher constraint on the business model forces the utility to have a closer relationship with the local authorities. This type of integration has also its rituals, which are materialising these cross-sectoral dynamics (Box 1).

Box 1: The rituals of cross-sectoral practices

The implementation of cross-sectoral practices is a gradual process. This is the purpose of the weekly meetings that are held within the networks management team. The Monday meeting gathers all the members of the team: everyone details the key events that will rhythm the working week in a fairly relaxed atmosphere, where jokes are easily cracked. This is not only an important moment to coordinate all the calendars, but also a strategic time used to raise important issues for the management board, such as dysfunctions or points of tensions.

During my stay, I attended several meetings animated by fierce discussions on investment strategies. Many engineers considered that their amounts were fairly too low with regard to the needs of several sectors, and notably the water sector.

These meetings offer the advantage of enhancing the managers' knowledge regarding the different networks and their current constraints and needs. This helps, in a coordinated or at least well-informed way, in devising strategic plans for maintenance, development and investments in the various sectors. These discussions ahead of projects are intended to lower the level of conflict within the utility and to provide the company with more coherence and weight in discussions with local government.

In addition to this Monday ritual, a second weekly meeting has been institutionalised, every Friday. In these meetings, the different works are coordinated, in the presence of technicians from the city council. The goal of these gatherings is twofold: they are used as a way to check the level of completion of ongoing works and to ensure the coordination of future works. The meetings concern maintenance and repair works primarily for water, gas and heating networks. These tasks often require to open the ground and could potentially alter or block automobile traffic: this coordination between sectors allows the city to avoid the multiplication of inconveniences in the same street or district for a long duration by grouping together all the interventions or sequencing them in a coordinated manner. By limiting their duration, the economic efficiency of these works can thus be enhanced, along with their social acceptance. As such, this coordination reinforces the link with the local government and makes the utility a increasingly important player in the city planning.

Such an integration traverses not only all the operative sectors of the company, but also the customer services. This is particularly noticeable through one artefact: the bill/invoice. A customer receives only one bill from the SWM, covering all the sectors, with all the details for 
every sector. This artefact is also a discursive and concrete way of presenting the utility as a whole, as a real multi-utility and not the sole addition of small divisions in charge of different sectors. These tools reinforce the spatial anchoring of the utility and its directors' ambition to be a regional reference in urban services.

This cross-sectoral approach has direct consequences that transform the utility into what can be called a cross-utility, where every employee's practices embody the coupling of various sectors. This is even mirrored in the development of human resources within the utility. Theoretically, all employees must declare the number of hours they have devoted to each sector they have worked for. During my stay at the company, I never saw any employees quantifying exactly the time of each operation and determining the sector to which it was assigned. Whereas European regulations force companies to have separate accounts for each and every sector, one can easily imagine that these cross-sectoral practices and their reporting might be a way to adjust costs of personnel according to branches and to implement cross-subsidies in a discreet if not accidental manner. This form of reorganisation is not a unique case amongst Stadtwerke, yet it is quite paradoxical, for the liberalisation of energy markets (through the unbundling of accounts as specified in the article 31 of the directives 2009/72/EC and 2009/73/EC) had forced companies to individualise accounts for every sector. The political and strategic choice adopted by the utility takes a counter-intuitive path: it was when regulatory bodies required more separation between sectors that the utility decided to develop symbioses, synergies and cross-sectoral practices. This strong statement could be interpreted as a re-affirmation of the "Stadtwerkthinking" (Schöneich, 2012) and of the "strong local model" depicted by Lorrain (2005) in his analysis of the German model of (public) urban services.

Cross-sectoral practices are thus deeply transforming and reorganising the functioning of local utilities. The purpose of these emerging practices is mainly to enhance the company's general efficiency but it also encompasses a socio-political dimension, to ensure that no additional costs will be transferred onto the users ${ }^{5}$. Although efficiency-oriented, such a cross-sectoral perspective is not limited to a pure market-based vision. These practices are also materialised in some projects coupling various sectors, which epitomise another facet of these cross-sectoral dynamics.

\section{The rise of cross-sectoral projects: the example of the Rothensee incinerator}

The most emblematic material example of these cross-sectoral dynamics is probably the Rothensee incinerator, where waste, heat and electricity have been coupled and which was supposed, in the city's view, to contribute to the construction of a greener infrastructure. The MHKW (Mühlheizkraftwerk) was built in 2006 in the northern part of the city of Magdeburg, in the district of Rothensee and was meant to partly replace the former district heating network. This new plant can be seen as a palimpsest-factory: its development is made of strata that narrate the new arrangements of the socio-technical system through the coupling of sectors and its aim to be less dependent upon external economic factors (Author, 2015).

\footnotetext{
${ }^{5}$ As one of the three directors explained, they have opted for a strategy where they would increase the burden on the employees' side to limit price increases for the users, without dismissing any employee but by not replacing some. For instance, in the water sector, they managed to avoid any price rise from 1997 onwards.
} 
The previous supply system produced only heat and consisted of three plants using fossil energy, be that oil, gas or coal (map 1). Due to shrinking consumptions levels, they were all under-used, with high costs of maintenance and heavily dependent upon energy prices and consequently exogenous geopolitical factors, making the system economically and technically vulnerable or at least suboptimal.

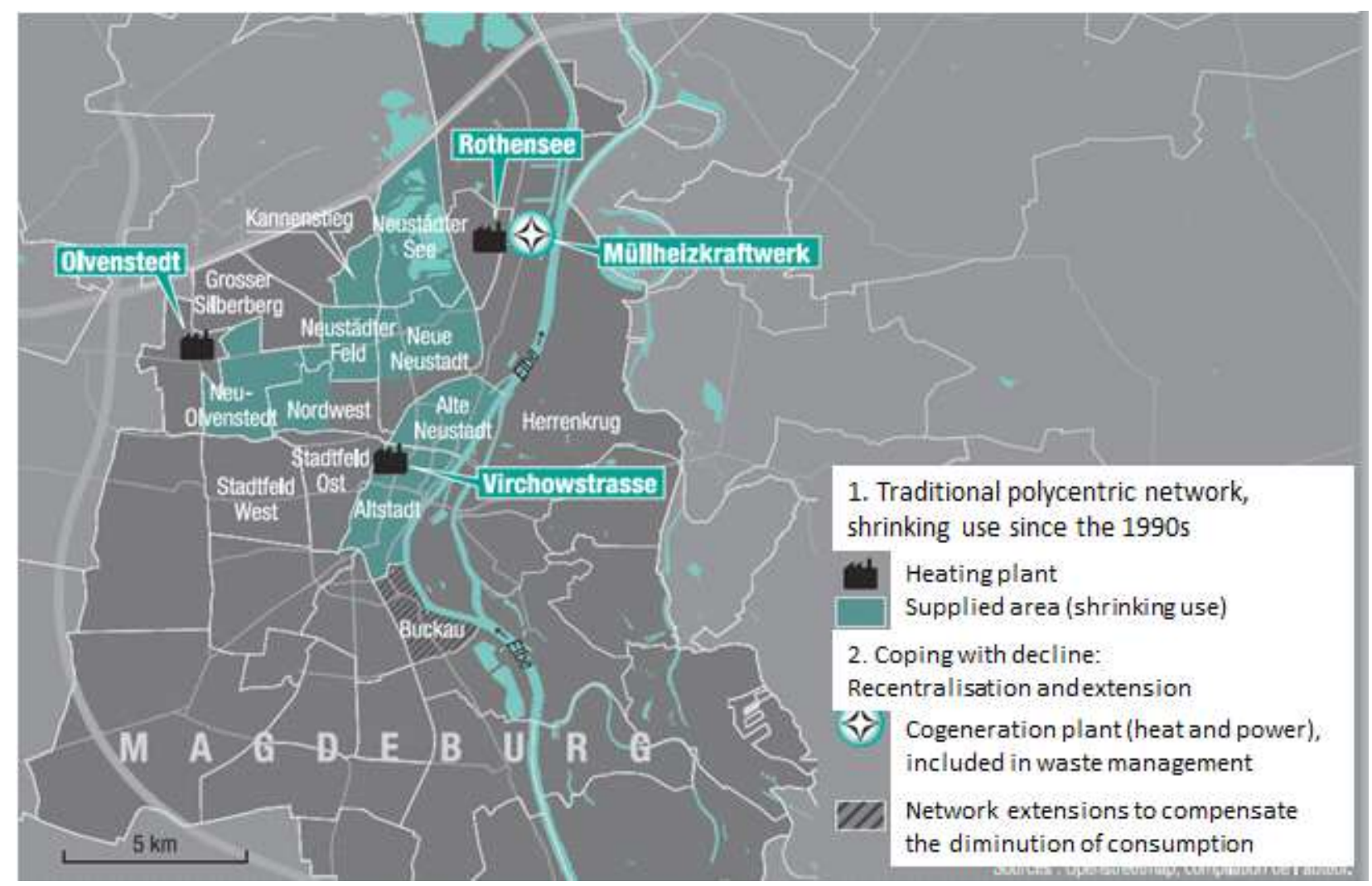

Map 1: Magdeburg and its recentralised and extended district heating system

Source: Openstreetmap and Author

In view of an unprecedented shrinking use of heat and therefore an increasingly oversized network, the multi-utility SWM built two scenarios. The first one was based on heat supply through decentralised small systems. A recent survey assessed this one as being too costly and unprofitable (Otto, 2013). The second scenario, which was implemented, consisted in recentralising the system, adapting it to lower consumption levels, and coupling waste management and energy generation. The new plant, which is an incinerator producing heat and power from the combustion of waste of high calorific value (compared to other contexts, c.f. de Bercegol, this issue), covers over $95 \%$ of heat demand ${ }^{6}$ (and 50\% of power demand) and has a maximum capacity of $125 \mathrm{MW}$. During the few hours per year when peak demand for heat reaches $165 \mathrm{MW}$, the former plant of Rothensee is activated as a back-up. Through this new infrastructure, SWM endeavours to adjust the capacity to changing consumption patterns and to the new consumption regime in both district heating and electricity systems. As the

\footnotetext{
${ }^{6}$ Peak demand can be supplied by the legacy plants when needed, which usually happens a few hours a year.
} 
diminution of consumption levels is still an ongoing process, SWM plans to progressively extend its network to new areas of the city (map 1): a territorial change, if not a change of scale, to adapt the socio-technical system to new consumption patterns.

By coupling these various sectors, production costs are substantially reduced and a new infrastructural ecology emerges, theoretically reliant on local resources. Even though incineration is often favoured politically ${ }^{7}$, this is considered a controversial if not suboptimal technique regarding waste management and resource efficiency (Dijkgraaf and Vollebergh, 2004). Yet, the incinerator in this case must be understood in a larger sociotechnical configuration that goes beyond sole waste management and where energy is produced and supplied at a very low cost.

At the time of its construction, this plant, which incinerates 600,000 tonnes of waste annually, was a pioneer throughout Bundesland of Saxony Anhalt. Its creation was also highly pushed by the city government, as it could be portrayed as part of the energy transition agenda shaped at national level (like in Moss and Hüesker, this issue). In such a new infrastructural ecology, the utility acts as the agent of transformation towards a theoretically more local electricity and heat production. Thanks to the MHKW, the city could comply with new federal regulations of $2006^{8}$ regarding waste treatment that require its incineration. This provides the city with so-called "green" energy sources, as this is produced through cogeneration processes. The rhetoric of resource efficiency is used by both the city government and the utility to discursively present this project (and, through it, the city) as a flagship of energy transition. The necessity for the utility to transform its technical and business model has thus converged with the political agenda of the city government's political agenda on energy transition.

Unlike many similar plants that are the subject of controversies or social protest (Rocher, 2008), the Rothensee incinerator has benefited from a high level of social and political acceptance: none of the political parties, including the Green party, contested this project. Two factors account for this: first, the chosen site has already hosted one of the former plants of the system: there was nothing new about having an industrial building in this area; second, civil society activism has been less preoccupied by environmental issues than by social questions regarding employment in the fairly disadvantaged district of Rothensee. Yet, in spite of the creation of new jobs, the long-term trend reflects an important diminution: 600 employees worked on this site in 1990, against only 38 in 2013, and the number of engineers has also dropped from 40 in 1990 to 2 in 2015.

Even if the employment benefits can be challenged, the construction of the MHKW initially entailed substantial advantages for the various users. The coupling has made district heating fairly cheaper than decentralised sources of heating. No local company that uses fossil fuels could compete with the low energy prices offered by MHKW. This has a twofold effect on the local political landscape: first, the territorial integration of the Stadtwerk has been reaffirmed,

\footnotetext{
7 This provides also a solution to regulations prohibiting (from June 2005 onwards in Germany) to dispose untreated waste on landfills and to eradicate landfill from waste management at the horizon 2020 (for details, see German Ministry of the Environment, 2005 )

${ }^{8}$ which confirmed and reinforced regulations of 1993 that limited landfill disposals to incineration residues.
} 
and its power position on the local energy market has been strengthened, partly due to converging interest with the city government; and second, the relationships between the Stadtwerk and its users - the municipal housing company and housing cooperatives - have been strengthened, as this pricing policy allows them to offer flats with lower service charges, thus making them comparatively more attractive under conditions of a low housing market pressure (due to urban shrinkage). In this new arrangement, the local utility consequently plays a reaffirmed political and material role in the local arena, which gives it some more influence in its negotiations with its main shareholder, the city's government.

\section{Discussion: tensions, politics of scale and the production of new vulnerabilities}

The narrative of cross-sectoral dynamics seems to offer interesting perspectives on more efficient or more sustainable infrastructure systems. Yet two aspects of this narrative require a closer look that may partly obscure the bright picture of a necessarily optimal integration of sectors, and contribute to a re-politicisation of these issues.

The first one relates to organisational changes and the development of new cross-sectoral practices. The transformation into a cross-utility has impacted the hierarchy within the utility and has redistributed resources and power. Even though these changes have been effected in a fairly efficient way, and have on the whole been welcomed, some tension remains. As one of the managers explained, "this is always the same. There is almost always money for projects regarding gas or electricity, but water is left aside. Usually, we run out of possible investments for the water sector in March or April every year" (conversation with a network manager, February 2013) $)^{9}$. In the reorganisation of the utility towards more integrated cross-sectoral management, some sectors seem to be favoured. The transition towards more coupling of infrastructure seems to be driven by the energy sector: the alignment of practices and projects is largely led by the energy divisions. This largely echoes Jaglin's and Verdeil's idea that "an urbanisation of energy issues" is occurring (2013): the city government demonstrates more interest in the politically and economically more visible and decisive issue of the time (energy), while slightly neglecting stagnating if not declining sectors (water). Accordingly, like any new form of professional practice, this turn triggers tensions between water and energy engineers that would contradict the very idea of an integrated management. This underlines the fact that integration is a very relational and political process and not a pure organisational tool, where power can be redistributed or reinforced within the utility.

The second element of discussion pertains to the supposedly "greener" infrastructure that crosssectoral projects like the Rothensee incinerator could produce. However innovative and integrative this sociotechnical solution may appear, it also generates new tensions and scalar issues. The period of time following the construction of the Rothensee incinerator was followed by the proliferation of new incinerators in the Land of Saxony-Anhalt, notably explained by the conjunction of peak oil prices since 2008 and waste regulations, particularly requirements made

\footnotetext{
${ }^{9}$ Investment in the water sector amounted $€ 6,98 \mathrm{M}$ in 2001 and has constantly decreased to reach $€ 2,43 \mathrm{M}$ in 2010 and $€ 3$,1Min 2013. The practices of re-bundling have mainly reinforced an ongoing process.
} 
at the national level to develop waste incineration. These regulations have fostered contradictory injunctions, promoting waste incineration to supply energy systems with local resources while encouraging a diminished waste production. This translates into scalar paradoxes with material effects. Waste has become not only a crucial resource, but also a limited resource subject to chronic shortfalls that have been largely underestimated or neglected. While waste demand for incineration amounts to 2,3M tonnes annually in the Land of Saxony Anhalt, $40 \%$ of it cannot be provided locally. Waste is becoming a political and geographical issue, and a factor of instability for numerous local district heating systems in the area. The coupling of infrastructures has also transformed this waste management issue into a larger one, including heating and electricity systems, making the local waste and energy system more vulnerable, in particular in relation to the external factors that this transformation was supposed to limit.

This has resulted in the gradual creation of highly competitive international waste market, benefiting from the lack of regional or national regulation and coordination. In the city of Magdeburg for instance, the Rothensee plant incinerates $40 \%$ of local waste but has therefore to import $60 \%$ of waste from other parts of Germany, Ireland or Switzerland. Scale was here largely overlooked or underestimated here by both regional political representatives and the SWM directors. A new politics of scale emerged through the implementation of cross-sectoral projects, enhancing competition between territories, increasing the recourse to distant resources and consequently making it contradictory with the objectives of a low-carbon economy. Unlike many studies, the scarcity of a resource is not the driver for the development of cross-sectoral projects but actually one of its consequences.

This market approach contradicts the idea of local energy generation. The technical turn associated with the MHKW project highlights the potential new vulnerabilities that this can engender: technical due to shortfalls, economic due to dependency on volatile market prices. The MHKW has been presented by both the utility and the city government as the material flagship of an energy and urban sustainable transition relying on local resources that turn out to be not quite local nor consequently sustainable. The high level of interdependency created between waste management, district heating, and power systems produces new forms of vulnerability for each sector, threatening the continuity of their functioning or making it to contingent on market-based and consequently exogenous factors. The new infrastructural ecology thus created converges with similar tensions and problems, not unlike those of the one it was supposed to replace.

\section{Conclusions}

What the Magdeburg story reveals is a form of reorganisation of local utilities, where the development of cross-sectoral dynamics contributes to a modernisation of the company and to an adaptation to socio-economic and environmental challenges, somewhat encouraged by local government and national regulations. This form of re-bundling of infrastructure constitutes both the premises of a new infrastructural and urban trajectory. Its cohabitation with processes of un-bundling that have marked many reforms in the world of infrastructures is one of the key challenges in terms of urban governance and a central point for research agendas on energy 
transitions and the hybridisation of governance models around this transition. The SWM offers an example of potential bypass of this strict unbundling through cross-sectoral practices. The transformation of the multi-utility into a cross-utility enables new forms of collaborations and synergies that were formerly neglected and can be deepened, transforming and strengthening its role in the urban arena.

The new ecology produced by this reorganisation of a local utility should not however be interpreted as an uncontested process simply creating more reliable, greener, and sustainable urban systems. Like any transformation of these socio-technical objects, this transformation shifts tensions or generates new ones, within and outside the utility. In the industrial fabric of urban services, the coupling of urban networks has its political dimension, and although this seems to enable innovative and interesting dynamics to change energy production, this often happens at the expenses of other sectors such as the water sector. There is consequently a need to further develop the water-energy nexus approach within utilities, to ensure a balanced treatment of the various sectors.

The Rothensee story - a system relying on waste incineration to be theoretically more local and lacking of resources due to the development of similar infrastructures at a regional level - also demonstrates also the importance of spatial issues in the development of cross-sectoral projects. This demonstrates the importance for both the city government and research to analyse all the effects at all scales of new material arrangements relating to the bundling of infrastructures. This also illustrates the need for the urban research on energy to take into account this scalar issue and its corollary, the potentially increased vulnerability of urban technical systems: benefits in one situation could result in greater vulnerability at a different scale. These projects are often conceived of at a local level and insufficiently conceptualised and contextualised at higher levels, producing new forms of vulnerabilities that are affecting not only the infrastructure itself, but the urban areas supplied by this infrastructure. This lack of resources producing new markets and political and scalar issues constitutes a vibrant confirmation of Jane Bennett's famous quote that "matter matters, but politically" (Bennett, 2010), all the more insofar as coupled infrastructures augment the sources of matter that actually politically matter.

\section{Bibliography}

Ambrosius G (2012) Geschichte der Stadtwerke. In: Bräunig D and Gottschalk W (eds.) Stadtwerke. Grundlagen, Rahmenbedingungen, Führung und Betrieb. Baden-Baden: Nomos, pp.35-51.

Barraqué B, Isnard L, Montginoul M, Rinaudo JD and Souriau J (2011) Baisse des consommations d'eau potable et développement durable, Responsabilité et Environnement (63) : 102-108.

Bazilian M, Rogner H, Hoells M, Hermann S, Arent D, Gielen D, Steduto P, Mueller A, Komor P., Tol, $\mathrm{R}$ and Yumkella K (2011) Considering the energy, water and food nexus: towards an integrated modelling approach. Energy Policy (39): 7896-7906.

Beddington J (2009) Food, energy, water and the climate: a perfect storm of global events? London: Government Office for Science.

Bennett J (2010) Vibrant Matter. A political ecology of things, Durham (USA): Duke University Press. 
Callon M (1987) Society in the Making : the Study of Technology as a Tool for Sociological Analysis. In: Bijker W, Hughes T and Pinch T (eds.) The Social Construction of Technical Systems : New Directions in the Sociology and History of Technology. Cambridge: MIT Press, pp.83-103.

Cousins JJ and Newell JP (2015) A political-industrial ecology of water supply infrastructure for Los Angeles. Geoforum (58): 38-50.

Coutard O (2010) Services urbains : la fin des grands réseaux ? In : Coutard O and Lévy JP (eds.), Ecologies urbaines. Paris: Anthropos, pp.102-129.

Coutard O and Rutherford J (2016) Beyond the networked city: an introduction. In: Coutard O and Rutherford J (eds.) Beyond the networked city : infrastructure reconfigurations and urban change in the North and South. London: Routledge, pp.7-24.

Dijkgraaf E and Volleberg H (2004) Burn or bury? A social cost comparison of final waste disposal methods. Ecological Economics, 50(3): 233-247

Edgerton D (1999) From innovation to use: Ten eclectic theses on the historiography of technology. History and Technology 16(2) : 111-136.

Fender A and Poupeau FM (2007) L'émergence d'un nouveau mode de gouvernance locale des réseaux en Allemagne. Une ville moyenne et son Stadtwerk face au processus de libéralisation. Sociologie du Travail 49(4) : 366-382.

Gellings C (1996) Then and now : the perspective of the man who coined the term 'DSM'. Energy Policy 24(4): 285-288.

German Ministry of the Environmnent (2005), Bericht Siedlungsabfallentsorgung, online

Goldthau A (2014) Rethinking the governance of energy infrastructure: scale, decentralization and polycentrism. Energy Research and Social Science (1): 134-140.

Golubchikov O, Badyina A and Makhrova A (2014) The Hybrid Spatialities of Transition : Capitalism, Legacy and Uneven Urban Economic Restructuring. Urban Studies 51(4): 617-633.

Gottschalk W (2012) Strukturen und Organisation von Stadtwerken. In Bräunig D and Gottschalk W (eds.) Stadtwerke. Grundlagen, Rahmenbedingungen, Führung und Betrieb, Baden-Baden: Nomos, pp.53-72.

Graham S and Marvin S (2001) Splintering Urbanism. Networked Infrastructures, Technological Mobilities and the Urban Condition, London: Routledge.

Guigo D (1994) Ethnologie des hommes des usines et des bureaux, Paris : L'Harmattan,

Hardy L, Garrido A and Juana L (2012) Evaluation of Spain's Water-Energy Nexus. International Journal of Water Resources Development 28(1): 151-70.

Hawkey D and Webb J (2014) Coordinating Heat Network Development under Uncertainty: Nascent Heat Networks in Two British Cities. Heat and the City International Workshop. Sustainable Heating Provisions and Cities : Theory, Practice and Future Implications, Edinburgh, 32p.

Hillenbrand T, Sartorius C and Walz R (2008) Technische Trends der industriellen Wassernutzung. Karslruhe, Fraunhofer ISI Arbeitspapier.

Howitt R (1998) Scale as relation : musical metaphors of geographical scale. Area (30): 49-58. 
Jaglin S and Verdeil E (2013) Energie et villes des pays émergents : des transitions en question. Introduction. Flux (93-94): 7-18.

Katz J (2001a) Analytic Induction. In: Smelser N and Baltes P (eds.), International Encyclopedia of the Social and Behavioral Sciences.

http://www.sscnet.ucla.edu/soc/faculty/katz/pubs/Analytic_Induction.pdf

Katz J (2001b) From How to Why : On Luminous Description and Causal Inference in Ethnography. Part 1. Ethnography 2(4): 443-473.

King C, Holman A and Webber M (2008) Thirst for energy. Nature Geoscience (1): 283-286.

Kluge T and Scheele U (2008) Von dezentralen zu zentralen Systemen und wieder zurück? Räumliche Dimensionen des Transformationsprozesses in der Wasserwirtschaft. In Moss T, Naumann $M$ and Wissen M (eds.) Infrastrukturnetze und Raumentwicklung. Zwischen Universalisierung und Differenzierung, Munich: Oekom Verlag, pp.143-172.

Kothari R, Tyagi VV and Pathak A (2013) Waste-to-energy: A way from renewable energy sources to sustainable development. Renewable and Sustainable Energy Reviews 14(9): 3164-3170.

Krämer A (1993) Querverbund - la gestion transversale des services publics en Allemagne. In Barraqué B (ed.) La ville et le génie de l'environnement. Paris: Presses de l'Ecole des Ponts, pp.197-204.

Leck H, Conway D, Bradshaw M and Rees J (2015) Tracing the Water-Energy-Food Nexus: Description, Theory and Practice. Geography Compass 9(8): 445-460.

LHW (Landesbetrieb für Hochwasserschutz und Wasserwirtschaft Sachsen-Anhalt) (2012) Vernässung und Hochwasser in den Magdeburger Stadtteilen Rothensee und Eichenweiler. Magdeburg.

Little RG (2002) Controlling Cascading Failure: Understanding the Vulnerabilities of Interconnected Infrastructures. Journal of Urban Technology 9(1): 109-123.

Lorrain D (2005), Urban Capitalisms: European Models in Competition. IJURR 29(2): 231-267.

McFarlane C and Rutherford J (2008) Political Infrastructures : Governing and Experiencing the Fabric of the City. IJURR 32(2): 363-374.

Marston S (2000) The social construction of scale. Progress in Human Geography 24(2): 219-242.

Means EG (2004) Water and Wastewater Industry Energy Efficiency: A Research Roadmap; Denver: Water Research Foundation. http://www.waterresearchfoundation.org/research/topicsandprojects/execSum/2923.aspx

Monstadt J (2007) Urban Governance and the Transition of Energy Systems: Institutional Change and Shifting Energy and Climate Policies in Berlin, IJURR, 31(2): 326-343.

Monstadt J (2009) Conceptualizing the political ecology of urban infrastructures: insights from technology and urban studies. Environment and Planning A 41(8): 1924-1942.

Moss T (2008) "Cold spots" of urban infrastructure: shrinking processes in Eastern Germany and the Modern Infrastructural Ideal, IJURR 32(2): 436-451.

Naumann M and Bernt M (2009) When the Tap stays dry : Water Networks in Eastern Germany. Local Environment 14(5): 461-471. 
Otto L (2013) Analyse, Auswertung und Optimierung von Mini-Blockheizkraftwerken, Bachelor thesis, Universität Otto von Guericke, Magdeburg.

Pittock J (2011) National Climate Change Policies and Sustainable Water Management: Conflicts and Synergies. Ecology \& Society 16(2): 25.

Possmopoulous C, Bourka A and Themelis N (2009) Waste-to-energy: a review of the status and benefits in USA. Waste management (29): 1718-1724.

Rocher L (2008) Les contradictions de la gestion intégrée des déchets urbains : l'incinération entre valorisation énergétique et refus social. Flux (74) : 22-29.

Rutherford J (2014) The Vicissitudes of Energy and Climate Policy in Stockholm: Politics, Materiality and Transition. Urban Studies, 51(7): 1449-1470.

Santhosh A, Farid A and Youcef-Toumi K (2014) Real-time economic dispatch for the supply side of the energy-water nexus. Applied Energy (122):42-52.

Schöneich M (2012) Strukturwandel der Stadtwerke. In: Bräunig D and Gottschalk W (eds.) Stadtwerke. Grundlagen, Rahmenbedingungen, Führung und Betrieb, Baden-Baden: Nomos, pp.73-92.

Schulz-Nieswandt F (2012) Der Querverbund im Kontext kommunalen Wirtschaftens. In: Bräunig D and Gottschalk W (eds.) Stadtwerke. Grundlagen, Rahmenbedingungen, Führung und Betrieb. BadenBaden: Nomos, pp.181-198.

Scott C, Pierce S, Pasqualetti M, Jones AL, Montz B and Hoover J (2011) Policy and institutional dimensions of the water-energy nexus. Energy Policy 39(10): 6622-6630.

Scott C and Pasqualetti M (2010) Energy and water resources scarcity: Critical infrastructure for growth and economic development in Arizona and Sonora. Natural Resources Journal (50): 645-682.

Shove E (2016) Infrastructures and practices: networks beyond the city. In: Coutard O and Rutherford $\mathrm{J}$ (eds.), Beyond the networked city : infrastructure reconfigurations and urban change in the North and South, London: Routledge, pp.266-277.

Summerton J. (ed.) (1994). Changing Large Technical Systems, Boulder: Westview Press.

Swyngedouw E (1997) Excluding the other : the production of scale and scaled politics. In: Lee R and Wills J (eds.) Geographies of economies, London: Arnold, pp.167-176.

Sykora L and S Bouzarovski (2012) Multiple transformations: conceptualising the postcommunist urban transition. Urban Studies 49(1): 43-60.

UNESCO (2014) The United Nations World Water Development Report: Water and Energy, Volume 1. Paris.

(van) Vliet B, Chappells H and Shove E (2005) Infrastructures of consumption. Environmental Innovation in the Utility Industries, London; Earthscan.

Williams J, Bouzarovski S and Swyngedouw E (2014) Politicising the nexus: Nexus technologies, urban circulation, and the coproduction of water-energy. Brighton: Nexus Network Think Piece Series, $\mathrm{n}^{\circ} 1$. 